Universities Council on Water Resources

Journal of Contemporary Water Research \& EducAtion

ISSUE 144, PAGES 18-28, MARCH 2010

\title{
A Broken Hub Will Not Wheel: Water Reallocation in California
}

\author{
David Zetland
}

Agricultural \& Resource Economics, UC Berkeley, Berkeley, CA

Abstract: California's water transfer system depends on the Sacramento-San Joaquin Delta to move water. Unfortunately, the Delta's ecosystem appears to be suffering from this use - and other uses. After discussing the stakeholders in the Delta, the causes of ecological decline, and the choices for change (including a radical political-economic market), I conclude that businessas-usual is over, that any solution is costly, and that the politicians and bureaucrats in the middle of this process benefit from conflict and inaction. The Delta will remain broken for the foreseeable future.

Keywords: negotiation, political-economy, Sacramento-San Joaquin Delta

$\mathrm{T}$ The Sacramento - San Joaquin Delta is California's hydrological hub in a system that wheels water from where it falls in the north to where it is used in the south. This hub has been in operation since the 1940s, when the Federal Central Valley Project went into operation. In the 1970s, its importance grew as the State Water Project came on line. Even before the Delta was a hub, it was a place where people lived and farmed. It was also a place where fresh water from rivers (the Sacramento, San Joaquin and others) mixed with salty water from the San Francisco Bay to form a unique brackish ecosystem.

For many years, the Delta was all things to all people - a hub for moving water, a place to live and work, and a place of nature. Then the Delta estuary began showing strain. Among other signs was a decline in the health of the Delta Smelt, which lives in the Delta, and salmon and steelhead that migrate through the Delta as hatchlings going to sea and adults returning to spawn. ${ }^{1}$

A Dec. 14, 2007 decision by Judge Oliver W. Wanger of the US District Court in Fresno has made the Delta Smelt into one of the most (in)famous species in the West (Department of Water Resources 2007). In a nutshell, Wanger said that the pumps that export water from the Delta and into the Central Valley Project and State Water Project harm the smelt - both through higher mortality (they die of fatigue when the pumps affect water flows) and morbidity (they are weakened by changes in the salinity and competing with invasive spieces for food). Since the smelt is protected under the Endangered Species Act (ESA), its survival has a higher priority than operating the pumps. To protect the smelt, Wanger ordered pumps to be operated in accordance with guidelines designed by the US Fish and Wildlife Service (FWS). FWS issued these guidelines, in the form of a Biological Opinion, on Dec. 15, 2008. Since the Opinion has done nothing to ease pump operations, it is unpopular with groups that prefer otherwise. Wanger has also ordered a new Biological Opinion on salmon and steelhead, which is likely to find similar, adverse effects from pumping.

All of this "fishy" business is relevant because California was in its third year of drought. Recent exports from the Delta have averaged about 6 maf (million acre-feet), divided roughly 40/60 percent between the Central Valley Project and State Water Project. ${ }^{2}$ Deliveries in 2009 are currently projected to be $10 / 60$ percent of contracted volumes to Central Valley Project agricultural and urban interests and 40 percent to all State Water Project contractors. Although less than 20 percent of the reduction in deliveries can be blamed on the Wanger decision, every drop counts. ${ }^{3}$

For some, Wanger's decision was a welcome 
acknowledgement of trouble in the Delta. For others, Wanger's decision is a costly mistake. ${ }^{4}$ Although these positions appear irreconcilable, everyone does agree on one thing: The Delta is broken and should be fixed.

In this paper, I describe efforts to fix the Delta, beginning with relevant features (history, problems, and stakeholders) in the first three sections. In the next two sections, I discuss possible solutions. In the final section, I conclude that we are unlikely to see a Delta solution anytime soon. Why? It's not just that the problems are complex, but also because resolution would not benefit politicians and bureaucrats.

\section{Water and Fish versus Money and Votes}

Let us begin by oversimplifying history into two eras. ${ }^{5}$ Before World War II, California's population and economy was broadly compatible with its physical and biological characteristics. Many of the redwoods still stood, many rivers were not dammed, and many canals were local. ${ }^{6}$ Southern California had a smaller share of the state's population. Agriculture was labor intensive and locally irrigated. Food traveled a shorter distance to the table.

This world was not to last for long; change was already coming. During the 1930s, Hoover Dam, the Central Valley Project, and the Colorado River Aqueduct (which connects the Colorado River to urban Southern California) were under construction. Although the Depression and World War II had major impacts on these projects, the impacts basically sped things up. The defense industry grew near Los Angeles, agriculture became more mechanized, and technology (cars, roads, air conditioning) grew cheaper and more common.

After World War II, we entered an era of increasing prosperity. The Central Valley Project allowed dry-farmed land to be irrigated, the Colorado River Aqueduct allowed Los Angeles and other cities to expand, and petroleum allowed us to use more energy in more ways. This Age of Abundance continued well into the $1960 \mathrm{~s}$, when negative environmental impacts (smog, dirty water, vanishing forests, etc.) became too big to ignore.

The environmental movement moved from fringe (Silent Spring was published in 1962 and Science published "The Tragedy of the Commons" in 1968) to mainstream (Hardin 1968). In 1970 came the first Earth Day, the creation of the EPA, and a significant strengthening of the 1963 Clean Air Act. The Clean Water Act was signed in 1972. The environmental movement gained political strength because people worried about the increasing impact of negative externalities (unintended costs that you bear when someone else acts) on their lives. Because negative externalities are not factored into decisions made in markets (e.g., gasoline buyers do not pay for pollution), they are considered a variety of "market failure." The generic response to market failure is a call for political intervention, and the environmental movement uses political tools to advance their goals.

Here's the point of this long overview: The Delta has been instrumental in creating many economic benefits, but these benefits have come at an environmental cost. Since environmental issues are generally resolved through politics - not economics - it is hard to reconcile or trade economic benefits with political costs. (By the end of this essay, you may decide that "hard" is perhaps too soft a word! )

\section{Physical and Biological Features}

In its "natural" state, the Delta receives an average of approximately 21 maf of water from the Sacramento (85 percent) and San Joaquin (15 percent) rivers. These flows vary with precipitation (from lows of 8.5 maf to highs of 52 maf) and season (peaking in late-spring/early-summer). The variation in these flows and their interaction with the salt water of the San Francisco Bay has created a unique ecosystem. Historically, water would flow through into the Delta and west into the Bay and Pacific Ocean, via the Golden Gate (see Figure 1).

After gold was discovered in California in 1849, the population of the Bay Area rapidly increased. Settlers in the area found the Delta to be fertile but dangerous. The Sacramento and San Joaquin rivers would flood in winter. The Delta was a maze of peat islands and channels. This ecosystem was good for fish and bugs but not so great for cities and farms. So people began "fixing" things.

\section{Political and Economic Features}

The first major modification to the Delta 


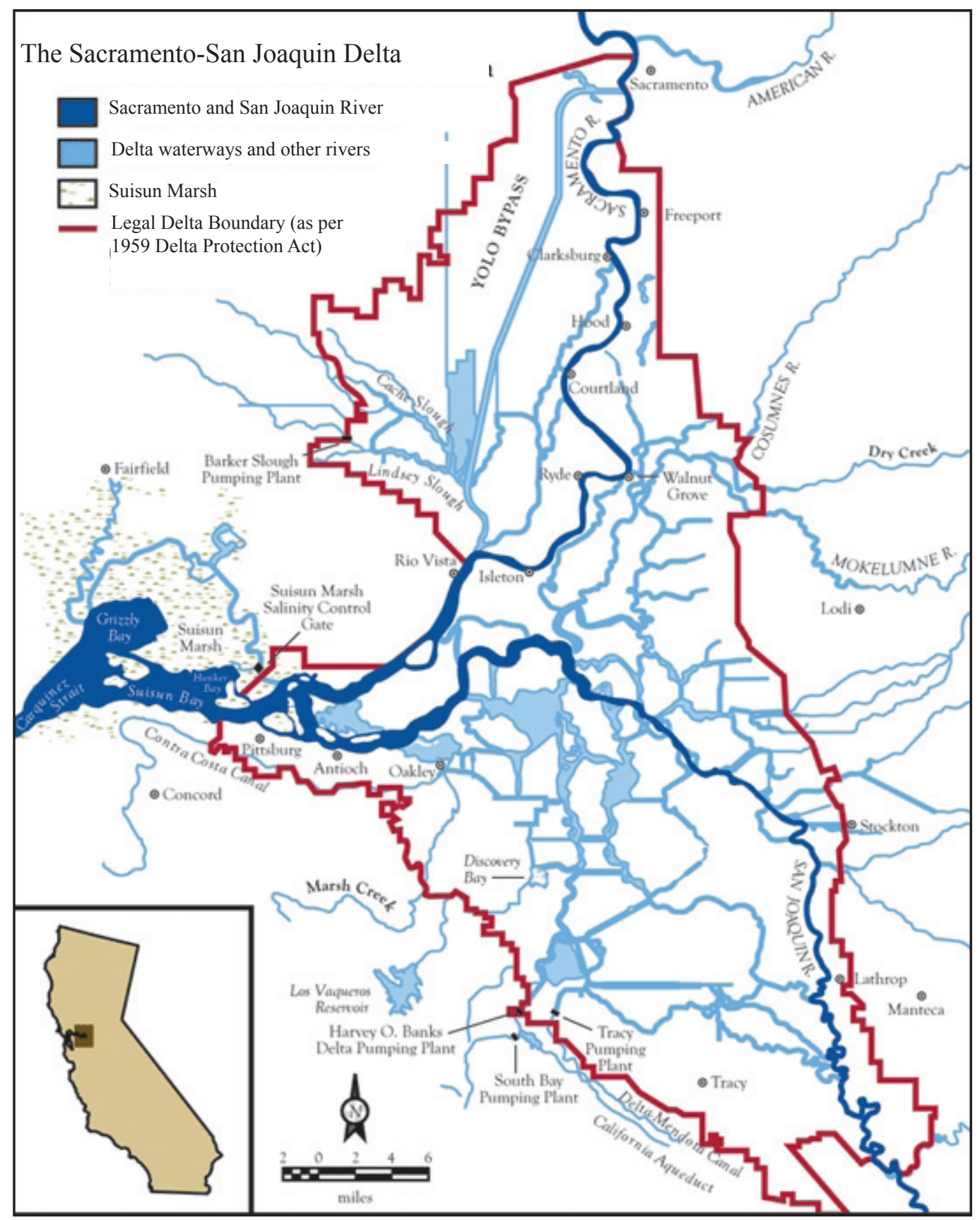

Figure 1. The Sacramento-San Joaquin Delta.

happened to the north, where surface water diversions from the Sacramento River were used for farming and mining. Both of these "beneficial uses" created property rights but the rights had different definitions. Farmers next to rivers had riparian rights to divert for local use. Miners (and farmers) with appropriative rights could divert for use elsewhere. The idea of appropriating water to be used away from the river or watershed was born in the western U.S. (Powell et al. 1879). Although appropriation was a good idea then, "over appropriation" has created complications. One obvious complication concerns return flows, seepage, etc. A riparian diversion will have a milder impact on local ecology than the same appropriative diversion.

The second major modification began with farming in the Delta. Farmers built levees to 


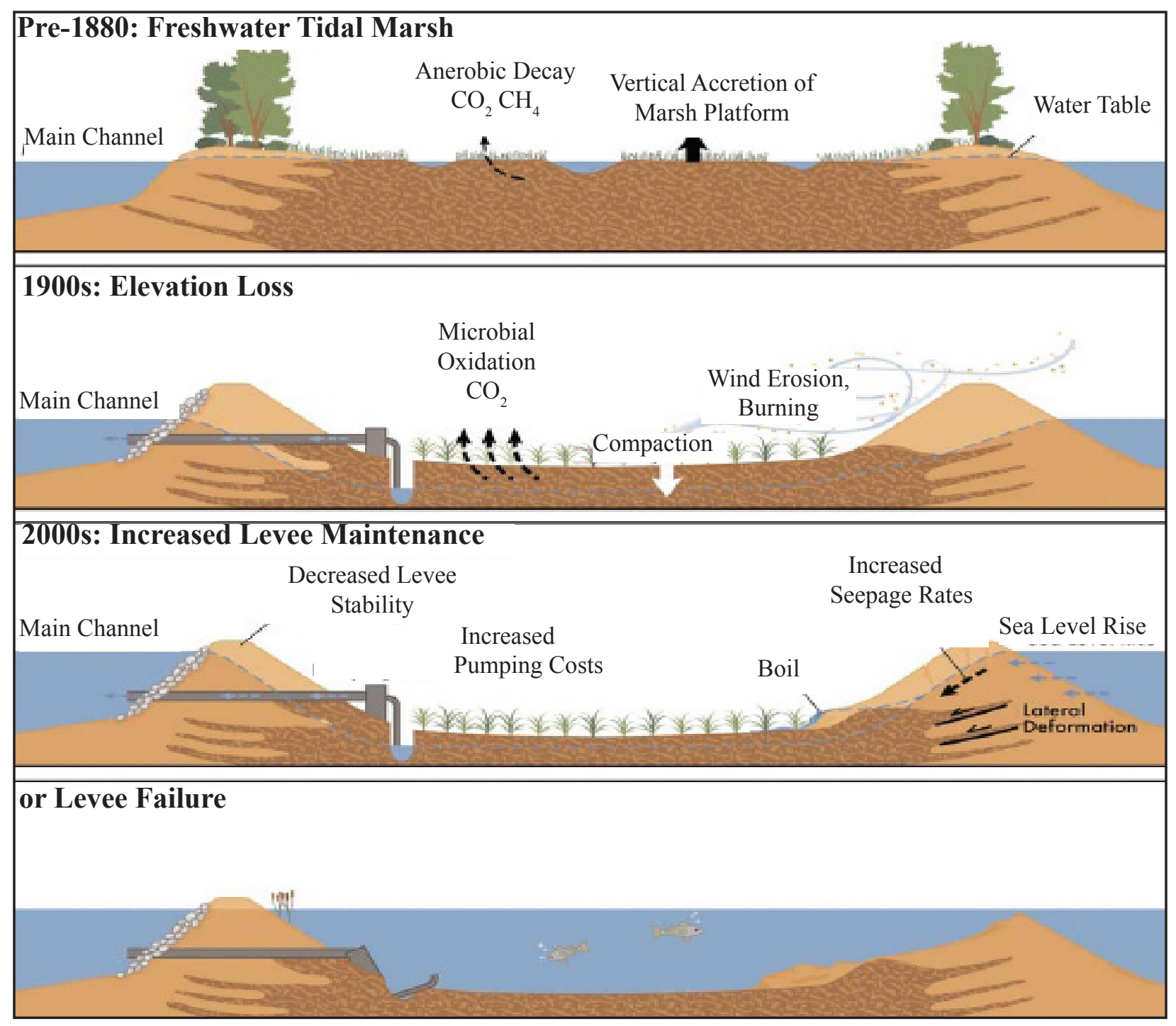

Figure 2. From islands and levees to polders and dikes to submerged land. (Source: Mount and Twiss 2005).

prevent flooding of Delta islands and to protect the rich, peaty soil. Over time, land elevation dropped from a combination of erosion, oxidization, compaction, and reduced augmentation from annual floods. When the surface dropped below sea level, islands and levees became "polders" and "dikes," respectively. These Dutch words brought Dutch technology - pumps that moved seeping water from inside dike-protected polders to the water channels outside (see Figure 2).

The third major modification began with the Central Valley Project, a massive system of 20 dams/reservoirs and hundreds of miles of canals north and south of the Delta designed to regulate water flows (reduce flooding and increase reliable delivery) and improve water quality (lower salinity) for communities and farmers north, south, and in the Delta. The biggest beneficiaries of the Central Valley Project were farmers south of the Delta. They got more water, of better quality, in places that had not received water in the past. The CVP had two major impacts: it dampened seasonal fluctuations in water flows to and through the Delta (drying out flooded areas and irrigating dry areas), and it redirected flows from the Delta. Central Valley Project pumps pulled water that normally flowed west and out the Golden Gate south and into the Delta-Mendota canal. Although exports were not absolutely large (perhaps 2-3 maf out of a total flow of $21 \mathrm{maf}$ ), they were large relative to the 
Table 1. Stakeholders, solutions and costs (estimated from capital costs with a five percent discount rate).

\begin{tabular}{lll}
\hline Supporters & Favored Action & Annual Cost \\
\hline In Delta & Save Delta & $\$ 250$ million \\
N and S of Delta & Peripheral Canal & $\$ 250$ million \\
Environmentalists & Radical Ecology & $\$ 4$ billion \\
Bureaucrats & Muddle Along & zero \\
\hline
\end{tabular}

volume and direction of natural flows.

The Central Valley Project's success attracted attention from farmers and urban interests in the southern end of the state, and the State Water Project was soon under consideration. ${ }^{7}$ The first contracts were signed in 1960 by an urban water wholesaler, the Metropolitan Water District of Southern California, which ended up with about half of all the contracts. The other contracts were signed by urban and agricultural contractors. In contrast to the Central Valley Project, most SWP water goes to urban areas. The State Water Project extended a trend begun by the Los Angeles and Colorado River Aqueducts: importing water from distant places to enable more people to settle in the dry region. Although some may claim that these projects brought water to the people, the reverse was also true. ${ }^{8}$

\section{What Killed the Fish?}

It's widely acknowledged that the Delta ecosystem has deteriorated, a result with many causes. In this section, I give a brief description of the leading suspects. All of the causes have some effect, but it is hard to attribute relative magnitudes. That do not keep people from assigning blame to others and deflecting criticism from themselves. Unfortunately, a lack of understanding (and agreement on attribution) makes it more likely that the cost and effectiveness of Delta ecosystem restoration will be higher in political, economic and biological terms. In the worst case, massive resource expenditure would result in no improvement.

\section{Levees and Subsidence}

The Delta was a wetland before the Gold Rush. Ever since then, "reclamation" has changed the ecosystem in artificial ways that reflect human priorities. Even worse, the Delta's geography has hardened around human institutions (roads, islands/polders, water flows and quality) - stifling the variability within which native species coevolved.

\section{Invasive Species}

The accidental and intentional introduction of invasive species (asian clam, striped bass, etc.) has harmed native species through competition over food and direct predation. Invasive species thrive in the artificially stable ecosystem that humans have created to maintain water quality for export. Interestingly, an effort to remove striped bass (a fish that competes with and eats smelt) is opposed by sport fishermen (Zieralski 2009).

\section{Water Flows and Quality}

Although the Sacramento River brings an average annual flow of about 18 maf to the Delta and about 18 maf of water flows through the Golden Gate each year, the timing, direction, and quality of these flows has changed. Spring floods no longer occur. Fresh water ebb and flow is dampened. Pumps that export from the southern end of the Delta change local water dynamics (timing, temperature, salinity, direction). Local and imported agricultural and urban discharges lower water quality. Numerous chemicals and residues of varying concentrations interact in ways that nobody understands.

\section{Climate Change}

Although the effects of climate change on the Delta are not yet troublesome, the arrival of (predicted) "flashier" water flows, warmer water, hotter temperatures, and higher sea levels will not be helpful. Things will be even worse if climate change increases demand and reduces supply in the state.

\section{All Water Politics Is Local}

Because the Delta lies at the heart of California's 
water distribution system, "local" events affect people in distant places. These people, naturally, complain when their situation deteriorates, and their politicians head off to Sacramento to lobby for relief. Unfortunately, the usual solution (throw money at the problem) is not available because it is very expensive to spend money to make water. ${ }^{9}$ Without money as a lubricant, politicians are forced to play a zero-sum game of water allocation where the gains to one group are the losses to another. Not surprisingly, these "games" are less about fun and more about high-stakes rhetoric, brinkmanship, and maneuvering. In this section, I describe the main stakeholders in the Delta. Table 1 gives an overview of the groups, their favored actions, and back-of-envelope annual costs of those actions (discussion actions and costs in Section "Fight and Compromise").

\section{Communities in the Delta}

Historically, most Delta residents have used local fresh water to grow crops. In the past 2030 years, the urbanization of the Bay AreaSacramento corridor has brought greater economic diversity to the area and increased the density of communication, natural gas, and rail and road networks. The Delta also has recreational value to locals and outsiders who enjoy its beauty, boating, and wildlife. The two million person Sacramento metropolitan area has affected the eastern side of the Delta. Floodplains have been drained, protected with levees, and developed. Urban areas draw out fresh water and discharge treated waste water (and sometimes raw sewage) in the Delta area.

These communities overwhelmingly support extending the status quo. Local farmers benefit from the north-south flow of water pulled by Central Valley Project and State Water Project pumps because the passing water stays fresh year-round. Local communities depend on State-supported levee maintenance to keep their "islands" dry and infrastructure operative.

\section{Communities South of the Delta}

People south of the Delta fall into three categories. The farmers on the east side of the San Joaquin Valley get their water from rivers and ground water. ${ }^{10}$ The farmers on the west side get their water from the Central Valley Project, State Water Project and ground water. Local communities are heavily dependent on agricultural production. Urban dwellers in Los Angeles and further south get their water from the State Water Project. Generally speaking, all of these communities want water exports from the Delta to continue.

\section{Communities North of the Delta}

Communities living in the Sacramento River watershed north of the Delta fall into two camps: Farmers who can use their water to grow local crops or sell that water downstream, and nonfarmers who benefit from farmers' economic activity. When farmers sell or lease their water, these non-farmers may suffer "third party impacts" from reduced economic activity. ${ }^{11}$ There is some controversy over the magnitude and direction of these impacts (positive, negative, zero), but many people believe they exist. These beliefs often lead to local ordinances prohibiting water transfers outside the area.

\section{Bureaucrats}

California's Department of Water Resources operates the State Water Project. The Bureau of Reclamation (BuRec) operates the Central Valley Project. Generally speaking, bureaucrats at these organizations want to keep water flowing into their projects. ${ }^{12}$ California's Department of Fish and Game and Environmental Protection Agency are similar to their Federal counterparts. They are culturally prone and legally directed to support policies that benefit the environment without regard to the economic costs of those policies.

These agencies have many overlapping interests, responsibilities and powers, which makes it difficult to know who can get what done. In 1994, the CALFED (CALifornia state agencies and the FEDeral agencies) Bay-Delta Program (CALFED) was formed to coordinate the actions of 25 bureaucracies with a stake in the Delta. After an initial surge of enthusiasm, activity and spending of billions of dollars, CALFED has been dismissed as ineffectual (Legislative Analyst's Office 2006). ${ }^{13}$ In 2006, Governor Schwarzenegger created the Delta Vision Blue Ribbon Task Force (Delta Vision) to extend CALFED. Delta Vision had more 
participants and a limited lifespan (two years), but it has no power to impose a solution. ${ }^{14}$

\section{Environmentalists}

Many environmental groups (many of them based in - and supported by citizens of - the San Francisco Bay Area) oppose water transfers as harmful for the local ecology, advise that water be used within its watershed, and lobby for discharge (waste water, storm water, tail water) that is free of contaminants (salt, ammonia, pesticides, fertilizers, etc.). They blame transfers for urban sprawl, loss of agricultural land, and wetland destruction. ${ }^{15}$ Since pumps that move water also use vast amounts of energy (the State Water Project uses 2-3 percent of the state's electricity), environmental groups decry the carbon footprint of the State's water operations. ${ }^{16}$

\section{Fight or Compromise?}

So we now arrive at the difficult part of this problem - how to reconcile stakeholders' desires into a solution that will "fix" the Delta. As I mentioned above, money (even other people's money) cannot fix the Delta. The environmental problems can only be addressed through actions, i.e., changes in water and land management. For example, west side farmers may not sell their water rights (so the water can stay in the Delta) because they value their farming "culture" or because such a deal is politically impossible to sell to local residents. ${ }^{17}$ Keep this reality (and the zero-sum nature of political and legal outcomes) in mind as we take a look at some proposals to fix the Delta. (Recall that Table 1 summarizes this information.)

\section{Muddling Along}

First note that business as usual is unacceptable. Programs to restore fish populations (hatcheries, temperature and salinity management and flow control) have not worked very well. North and south of Delta interests are upset by uncertain and changing restrictions on their water use. Although in-Delta communities would be happy to carry on, they are also concerned by uncertain regulations. Even worse, these communities are likely to face catastrophic flooding from rising sea level or earthquake-induced levee failure. ${ }^{18}$ Although communities (in, south and north of the Delta) and environmentalists do not like business as usual, politicians and bureaucrats have benefitted (accidentally or intentionally) from the endless study and wrangling over solutions. Remember who will lose influence and work if the Delta is "fixed."

\section{Save (Our Version of) the Delta!}

Lund et al. (2008: 258) estimated the capital cost of protecting current farm operations and "Delta community" to be at least $\$ 6$ billion. These funds would go towards levee repairs/upgrades and a salt water barrier that would prevent damage from earthquakes and rising sea levels, respectively. Since protecting built-up urban areas will cost $\$ 1$ billion, let's assume a marginal cost of \$5 billion to protect the Delta's rural and agricultural communities in their current form.

\section{Peripheral Canal}

A Peripheral Canal would convey water around the Delta to the pumps in the southern Delta. Lund et al. (2008) recommend the Peripheral Canal for three reasons:

- The Peripheral Canal would deliver higherquality water to the pumps while reducing problems with "strange" flow patterns that adversely affect native fish.

- The Peripheral Canal would allow the Delta's salinity to return to "natural" levels and variations, which is likely to help native fish and harm invasive species.

- The PC would increase export reliability in an area subject to risk from earthquakes and rising sea-level.

Opposition to the Peripheral Canal centers on three elements:

Cost: The Peripheral Canal is projected to cost $\$ 5$ billion and will require $2-3$ years to build. This will only happen if numerous and costly studies, lawsuits, and permits are settled in favor of the Delta. I estimate a minimum of five years to get through that preliminary and uncertain step.

Dead Fish: Native species may not recover after the Peripheral Canal is built.

Water Grab: South-of-Delta interests may 
Table 2. The market for solutions uses pledges to determine an action, pay the cost of the action and compensate losers.

\begin{tabular}{llllll}
\hline Action & Pledge & Cost & Votes & Population & Transfer \\
\hline Save Delta & $\$ 6$ bil & $\$ 5$ bil & 1 bil $(25 \%)$ & 3 mil & $+\$ 833 /$ capita \\
Peripheral Canal & $\$ 8$ bil & $\$ 5$ bil & 3 bil $(75 \%)$ & 15 mil & $+\$ 500 /$ capita \\
Radical Ecology & $\$ 90$ bil & $\$ 80$ bil & 10 bil & 16 mil & $-\$ 5,625 /$ capita \\
\hline
\end{tabular}

use the Peripheral Canal's capacity to export larger quantities of water, fueling "unsustainable" agricultural practices and urban development. ${ }^{19}$

These opponents repeat objections given the first time the Peripheral Canal was proposed. Voters defeated a Peripheral Canal proposal (via ballot initiative) in 1982 in one of the most lopsided votes ever. Over 90 percent of northern Californians opposed it; about 60 percent of southern Californians voted in favor.

\section{Radical Ecology}

Some feel that the best way to fix the Delta is to end human influence in the area. Taking the recent past as given, this would mean ending water exports, and restoring wetlands/land to a "natural" state. (Everyone agrees that restoration to pre-modern ecology would take many years and billions of dollars; more on that below.) Such a "restoration" would require massive adjustments to land use, employment and lifestyles.

All of these actions will have cash or opportunity costs. If water exports ended, then south-ofDelta interests would see their water supplies fall by 6 maf per year. This reduction adds up to, respectively, one-third, one-third and one-half of the water supply to the South Coast, San Joaquin and Tulare Lake hydrological regions (Department of Water Resources 2005: vol. 3). The mainly urban South Coast region could replace this supply (1.3 mafy) with reclamation or desalination at a cost of roughly $\$ 1.5$ billion/year. ${ }^{20}$

The mainly agricultural San Joaquin and Tulare Lake regions cannot afford to pay $\$ 1,200 /$ af for replacement supplies. Those regions would cope with reduced deliveries with a mix of water markets, conservation and fallowing. As an upper limit to this cost, assume that the four biggest agricultural counties in the region (Fresno, Kern, Merced and
Tulare) fallow their land and reduce their output in straight proportion to these water losses. Given gross agricultural output of $\$ 12.6$ billion and 33/50 percent fallowing by, respectively, Fresno/Merced and Tulare/Kern, that means an annual output reduction of $\$ 5.3$ billion (United States Department of Agriculture 2007). This number is an upper limit, since farmers will change their crop mix and increase water marketing and conservation. ${ }^{21}$

Note that the end of exports also means the end of annual operating costs from Central Valley Project/State Water Project pumping, treatment, etc. Assuming an 80/20 ag/urban split and costs of $\$ 30 / \$ 150 /$ af, the savings from not sending 6 mafy from the Delta would be about $\$ 320$ million/year. So, let's say that an upper limit on annual costs would be $\$ 5$ billion.

For an alternative calculation of this $\$ 5$ billion total, ${ }^{22}$ consider Lund et al. (2008), who say (p. 83) "ending water exports, as a long-term water supply solution, would probably cost at least $\$ 1.5$ billion per year or perhaps as much as $\$ 2.5$ billion" Let's call that $\$ 2$ billion.

As a ballpark figure, let's say that the cost of restoring wetlands would be about $\$ 1$ billion per year. ${ }^{23}$

Thus, radical ecology would cost from $\$ 3$ to $\$ 6$ billion per year. Let's use $\$ 4$ billion as a round number. ${ }^{24}$

Is $\$ 4$ billion a year expensive? That depends. As an absolute cost, it's less than one-quarter percent of the state's \$1.6 trillion economy. Relative to the one-time, capital cost of the Peripheral Canal ( $\$ 5$ billion), it's quite a lot. But then we have to consider the environmental value of a radicallyecological Delta relative to a Peripheral Canal or protected Delta. How much is that worth? Well, that's a subjective question that we can only evaluate with a "put your money where your mouth is" mechanism, i.e., markets. 


\section{Markets}

Markets are good for reconciling people's subjective values for goods. They are also good at testing the strength of people's "rock-solid" beliefs. After all, someone who claims that they would die for their point of view should be willing to pay for that view, right? While economists will agree with me, others may claim that "moral" questions are unworthy of filthy lucre. In other words, they would rather spend other people's money. Obviously nonetheless, consider this "market" method of reconciling diverging beliefs.

Begin with three different options (save the Delta, peripheral canal, radical ecology). Now allow individuals (not organizations) to pledge money (not votes) to their choices. Money pledges are assigned, first, to the total - not annual - cost of each choice. Assuming a five-percent discount rate, that means $\$ 5$ billion to protect Delta communities, $\$ 5$ billion for the PC, or $\$ 80$ billion for radical ecology. Remaining money pledges are then assigned to "votes," and the choice with the most votes wins. Here's the cool part: Money from the winners goes to the losers in proportion to their votes.

For example, Delta residents pledge $\$ 6$ billion, Peripheral Canalers pledge $\$ 8$ billion, and radicals pledge $\$ 90$ billion. After deducting "costs," these pledges result in, respectively, 1 billion, 3 billion and 10 billion votes for each choice. Since the radicals are willing to pay the most, they give $\$ 10$ billion to Delta residents and PCers, who divide that money $25 / 75$ in proportion to their votes. See Table 2 for a summary of this process.

Let's say that there are 3 million Delta supporters, 15 million Peripheral Canal-supporters (3 million from the Valley and 60 percent of the southern coast's 20 million population - in line with the share who voted for the Peripheral Canal in 1982) and 16 million radicals (8 million from the San Francisco Bay Area plus 40 percent of the 20 million people on the southern coast). That means per capita payments of $\$ 833$ to Delta residents, $\$ 500$ to PCers and $\$ 5,625$ from radicals ( $\$ 625$ transfer plus $\$ 5,000$ to implement the plan). If participation is lower than 100 percent, per capita numbers will rise. In fact, it's easily possible that pledges will not even rise above cost. If that happens (e.g., radicals pledge $\$ 10$ billion -12.5 percent of the cost of their vision), then we know who really believes - and who wants others to pay for their beliefs.

\section{Back to the Future?}

So what will happen? ${ }^{25}$ Some people have very strong feelings about the Delta and how it should be managed. Most of them prefer to fight in the courts and legislature - attempting to get their preferred outcome at low cost to themselves and a much higher cost to others. In short, we will see continued conflict (perhaps 3-4 years) over the right to allocate "Other People's Money" towards the pet projects of each special interest. Politicians and bureaucrats have every reason to encourage this fracas. The former because they can wield power (and collect "persuasive" campaign contributions); the latter because many of them earn a living "working" on a solution. Who loses? The fish.

\section{End Notes}

1. Although the winter-run Chinook salmon population was known to be in steep decline over twenty years ago, responses were mostly ineffective. The 1992 Central Valley Project Improvement Act (CVPIA) dedicated 800 taf of water to restoring the health of fisheries, but health did not return.

2. One million acre feet ( $\mathrm{maf}$ ) is 1,235 gigaliters. One acre-foot is about 326,000 gallons.

3. According to Martin (2009), the California Department of Water Resources calculates that Wanger-related water restrictions to protect the Delta Smelt reduce Central Valley Project/State Water Project deliveries by 420 taf (16 percent) in dry years and 2.09 maf (30 percent) in wet years.

4. In May 2009, Wanger ordered the U.S. Fish and Wildlife Service to consider the impact of reduced pumping on humans and communities.

5. Read Department of Water Resources (2005) or Carle (2009) to learn about California's current water situation. To learn about California's water development, read Boyle et al. (1971); Kahrl(1979); Gottlieb and FitzSimmons (1991); Hundley Jr. (1992); Reisner (1993).

6. Although many canals - All-American Canal, Hetch Hetchy Aqueduct, Los Angeles Aqueduct - transported water over long distances, they were typically gravity fed and had smaller capacities. 
When the Colorado River Aqueduct went online in 1941, it opened an era of larger canals that moved water with pumps.

7. Northern Californians unsuccessfully opposed State Water Project funding in a 1960 vote. In 1982, they were successful at blocking the State Water Project's "completion" - the Peripheral Canal (more below).

8. In some places, people only settled after water arrived; see Sections 3.3 and 6.5 in Zetland (2008).

9. Desalination and reclamation cost about $\$ 600$ and $\$ 1,200 /$ af, respectively. Water users pay about $\$ 5$ to $\$ 500 /$ af, a price that reflects the cost of delivery.

10. I include the Exchange Contractors in the east side because their legal water rights come from there.

11. Technically, farmers do not own water but water rights (usufructory rights), and these rights are often leased for one season. Like many, I say "water is sold" when I should really say "the usufructory water right is temporarily leased."

12. In Minton (2009), Department of Water Resources's former Deputy Director points out that they get over 90 percent of their budget from State Water Project revenue.

13. Minton (2009) says that its structure - consensus and all things to all people - meant that it was designed to fail.

14. Fortunately, CALFED and Delta Vision have produced massive volumes of scientific, economic and policy documents. See, respectively, http:// www.calwater.ca.gov and http://deltavision.ca.gov.

15. Some environmental groups (e.g., Environmental Defense Fund) support sustainable water transfers as a means of maximizing the social benefit from water.

16. The Central Valley Project produces a net surplus of electricity from its hydroelectric capacity, but it would be an even bigger net producer if it didn't use most of its electricity for pumping.

17. It is widely believed that west side farmers are willing to compromise on most things when there is enough money at stake, and that they use "cultural damage" as a negotiating tactic, but there are certainly people who take farming and community seriously enough to resist all buyout offers.

18. These dangers are outlined in Heberger et al. (2009) and Lund et al. (2008), respectively. For a rejoinder to the earthquake scenarios in Department of Water Resources (2009) - but similar to those in Lund et al. (2008) - see Adams et al. (2007).
19. The proposed design has high capacity to allow heavy exports during high-flood periods. These exports are supposed to allow for reduced exports in low-water periods. Skeptics think that this "big gulp, little sip" operational plan will turn into "big gulp, bigger gulp" operational reality; see, e.g., Minton (2009).

20. They could reduce demand through higher prices and/or conservation at a much lower cost; see Loaiciga and Renehan (1997). Also note that "homegrown" supplies are more reliable - a feature that's very valuable to local water managers and politicians.

21. On the one hand, it does not reflect "income multipliers," losses in capitalized land and/or equipment values, etc. On the other hand, these are gross revenues, not net profits.

22. They use the entire San Joaquin/Tulare hydrological region and assume agricultural areas sell water to cities. I assume that those cities get that water from desalination, reclamation, etc., leaving more water in the region.

23. I ignore the value of land in the Delta for two reasons. First, those lands will not suffer reduced water deliveries. Second, those lands may be submerged by rising sea level or earthquake. I also ignore the cost/benefit (of protecting the islands from inundation) to non-Delta communities that get their water, gas, etc. from networks crossing the Delta.

24. Economists will note that I have not included the deadweight loss from reduced consumption of water. I exclude this loss for two reasons: This surplus could now arrive from the environmental benefits of a restored Delta and/or this surplus never existed, i.e., "too large" past exports created welfare losses. Let's just say that deadweight losses are zero.

25. For alternative views of the future, see Blue Ribbon Task Force (2008); Lund et al. (2008); Minton (2009).

\section{Acknowledgements}

I thank Phil Bowles, Shawn Coburn, Kevin Dick, Jan Dougall, Bill Eisenstein, Claudia Goss, Ann Hayden, Richard Howitt, Tyler McMahon, Jeff Michaels, and Jonas Minton for conversations and comments on this topic and earlier drafts. The opinions expressed here are my own. 


\section{Author Bio and Contact Information}

David Zetland received his $\mathrm{PhD}$ in Agricultural and Resource Economics from UC Davis in 2008. He is now a S.V. Ciriacy-Wantrup Postdoctoral Fellow in Natural Resource Economics and Political Economy. He blogs on water, economics and politics at aguanomics.com. He can be contacted at dzetland@gmail.com or Agricultural \& Resource Economics, 210 Giannini Hall, University of California, Berkeley 94720-3310.

\section{References}

Adams, R., B. Gilbert, K. Hayhoe, B. Marcuson, J. Moore, A. Mynett, D. Neimeier, K. Rose, and R. Shlemon. 2007. Review of the Delta Risk Management Strategy Phase 1 Report. DRMS Independent Review Panel, Draft 4, CALFED Science Program.

Blue Ribbon Task Force. 2008. Delta Vision Strategic Plan. Final Report, Delta Vision, Sacramento.

Boyle, R. H., J. Graves, and T. H. Watkins. 1971. The Water Hustlers. Sierra Club, San Francisco.

Carle, D. 2009. Introduction to Water in California. California Natural History Guides. University of California Press, Berkeley.

Department of Water Resources. 2005. California Water Plan Update. Bulletin 160-05, California Department of Water Resources, Sacramento.

Department of Water Resources, 2007. DWR releases water delivery impact estimates following Wanger decision. Dec 24 Advisory, Department of Water Resources, Sacramento.

Department of Water Resources. 2009. Delta Risk Management Strategy Report. Final Phase 1 Report, Department of Water Resources, Sacramento.

Gottlieb, R. and M. FitzSimmons. 1991. Thirst for Growth: Water agencies as hidden government in California. University of Arizona Press, Tucson.

Hardin, G. 1968. The Tragedy of the commons. Science, 162(3859):1243-1248.

Heberger, M., H. Cooley, P. Herrera, P. H. Gleick, and E. Moore. 2009. The Impacts of Sea-Level Rise on the California Coast. Draft Paper CEC-500-2009024-D, California Climate Change Center.

Hundley Jr., N. 1992. The Great Thirst: Californians and water, 1770s-1990s. University of California Press, Berkeley.

Kahrl, W. L. 1979. The California Water Atlas. State of California, Sacramento.

Legislative Analyst's Office. 2006. Reforming the
CALFED Bay-Delta Program. Budget Review Report, Legislative Analyst's Office, Sacramento.

Loaiciga, H. A. and S. Renehan. 1997. Municipal water use and water rates driven by severe drought: A case Study. Journal of the American Water Resources Association, 33(6):1313-1326.

Lund, J., E. Hanak, W. Fleenor, W. Bennett, R. Howitt, J. Mount, and P. Moyle. 2008. Comparing Futures for the Sacramento-San Joaquin Delta. Report, Public Policy Institute of California, San Francisco.

Martin, W. 2009. Global Changes - Local Impacts: Managing Drought in the Golden State. Presentation to the 33rd International Carrot Conference, Department of Water Resources, Sacramento. Available at groups.ucanr.org/carrotconf2009/ files/61960.pdf.

Minton, J. 2009. California's Water Mess: How Did It Go So Wrong and Why it Could Happen Again. Working Paper, 20 Apr. http://www.lhc. ca.gov/studies/activestudies/watergovernance/ MintonApr09.pdf.

Mount, J. and R. Twiss. 2005. Subsidence, sea level rise, and seismicity in the Sacramento-San Joaquin Delta. San Francisco Estuary \& Watershed Science, 3(1).

Powell, J. W., W. Drummond, C. E. Dutton, G. K. Gilbert, and A. H. Thompson. 1879. Report on the lands of the arid region of the United States with a more detailed account of the lands of Utah. Geographical and Geological Survey of the Rocky Mountain Region. Government Printing Office, Washington, DC.

Reisner, M. 1993. Cadillac Desert. Penguin Books, New York.

United States Department of Agriculture. 2007. Census of Agriculture. Five-yearly Report, US Department of Agriculture.

Zetland, D. 2008. Conflict and Cooperation Within an Organization: A Case Study of the Metropolitan Water District of Southern California. PhD thesis, UC Davis. http://ssrn.com/abstract=1129046.

Zieralski, E. 2009. Fishermen fight for right to catch striped bass. San Diego Union-Tribune, 9 May. 